\title{
ANALISIS POLA ADOPSI TEKNOLOGI 3G PADA KALANGAN MAHASISWA UNIVERSITAS INDONESIA BERDASARKAN MODEL SARKER DAN WELLS DENGAN MENGGUNAKAN TEKNIK STRUCTURAL EQUATION MODELING
}

\author{
Alida Widianti dan Muhammad Rifki Shihab \\ Fakultas Ilmu Komputer, Universitas Indonesia, Depok, Indonesia
}

\begin{abstract}
Abstrak
Beberapa tahun terakhir, muncul teknologi telekomunikasi baru yang disebut 3G. Secara umum, penggunaan 3G di Indonesia belum meluas dan merata. Melihat perkembangan penggunaan 3G di Indonesia tersebut, peneliti ingin mengetahui faktor yang paling berpengaruh terhadap adopsi $3 \mathrm{G}$ pada masyarakat Indonesia dengan mengambil populasi mahasiswa Universitas Indonesia. Pola adopsi 3G dapat diteliti berdasarkan beberapa model adopsi teknologi yang ada. Peneliti memilih Sarker's and Wells' Framework sebagai dasar hipotesis penelitian karena model-model adaptasi teknologi yang lain seperti Technology Acceptance Model dan Unified Theory of Acceptance and Use of Technology dinilai hanya menggambarkan teknologi secara umum sehingga kurang mempertimbangkan faktor-faktor khusus sehubungan dengan sifat dari 3G. Peneliti menyusun kuesioner tentang adopsi 3G dari model SEM yang dibangun berdasarkan Sarker's and Wells' Framework, kemudian menyebarkannya pada sampel mahasiswa Universitas Indonesia. Proses penyusunan model sampai interpretasi hasil perhitungan dilakukan dengan Structural Equation Modeling. Hasil analisis yang dilakukan menunjukkan bahwa saat ini framework milik Sarker dan Wells yang digunakan untuk menggambarkan adopsi perangkat mobile tidak cocok diterapkan pada adopsi teknologi 3G di Indonesia dengan populasi mahasiswa Universitas Indonesia.
\end{abstract}

Kata kunci : 3G, model Sarker dan Wells, teknik Structural Equation Modelling.

\section{Pendahuluan}

Pada awal milenium ketiga, muncul teknologi baru yang disebut $3 \mathrm{G}$. Teknologi ini memungkinkan lalu lintas telekomunikasi data dengan kecepatan lebih tinggi. Oleh karena itu, teknologi ini memungkinkan layanan yang sebelumnya tidak dapat dilakukan karena keterbatasan kecepatan, misalnya layanan video call. $3 \mathrm{G}$ juga mendukung akses mobile TV dimana kita dapat menonton tayangan televisi melalui telepon seluler yang kita gunakan. Selain jenis layanan yang bertambah, $3 \mathrm{G}$ juga meningkatkan kemampuan layanan akses internet sehingga memudahkan para pengguna untuk mendapatkan informasi yang mereka butuhkan dalam waktu yang singkat.

Sejak September 2006, Indonesia sudah mulai mengenal layanan 3G. Perkenalan 3G pada masyarakat dilakukan baik dari sisi operator telepon seluler yang mulai menyediakan layanan $3 \mathrm{G}$ untuk para pelanggannya, maupun dari para produsen telepon seluler yang telah melempar banyak versi perangkat yang memadai dalam penggunaan teknologi tersebut ke pasar. Tetapi secara umum penggunaan $3 \mathrm{G}$ di Indonesia belum meluas dan merata. Layanan-layanan 3G belum bisa menggeser SMS dan voice call sebagai layanan unggulan dari para operator telepon seluler, walaupun laporan penggunaan $3 \mathrm{G}$ oleh salah satu operator selular di Indonesia sampai Juli 2007 menunjukkan bahwa pelanggan $3 \mathrm{G}$ di Indonesia masuk 10 besar jumlah pengguna $3 \mathrm{G}$ di dunia [1]. Fakta ini berlawanan dengan prediksi International Data Corporation (IDC) pada awal peluncuran teknologi 3G di Indonesia pada akhir tahun 2006. Lembaga tersebut memperkirakan bahwa jumlah pelanggan $3 \mathrm{G}$ di Indonesia hanya akan menjadi urutan terbawah di pasar 3G ASEAN. Prediksi tersebut didasarkan atas krisis ekonomi yang melanda masyarakat Indonesia.

Melihat perkembangan penggunaan $3 \mathrm{G}$ di Indonesia tersebut, peneliti ingin mengetahui faktor yang paling berpengaruh terhadap adopsi $3 \mathrm{G}$ pada masyarakat Indonesia dengan mengambil populasi mahasiswa Universitas Indonesia.

Tujuan penelitian ini adalah sebagai berikut:

1. Mengetahui apakah framework milik Sarker dan Wells cocok diterapkan pada penerimaan teknologi 3G di Indonesia. 
2. Mengetahui faktor yang paling berpengaruh dalam adopsi teknologi $3 \mathrm{G}$ di Indonesia sesuai dengan framework milik Sarker dan Wells.

Hipotesis-hipotesis penelitian ini berasal dari pemetaan pengaruh antar variabel terhadap adopsi teknologi 3G di Indonesia. Variabel-variabel dan masing-masing pengaruhnya diadaptasi dari framework milik Sarker dan Wells yang meneliti tentang pengaruh antar variabel terhadap adopsi perangkat mobile.

Hipotesis-hipotesis tersebut adalah:

$\mathrm{H} 1$ : Individual Characteristics berpengaruh pada

Use Process (Proses Penggunaan)

H2: Communication Characteristics (Karakteristik

Komunikasi) berpengaruh pada Use Process

(Proses Penggunaan)

H3: Modality of Mobility (Karakteristik Mobilitas)

berpengaruh pada Use Process (Proses

Penggunaan)

H4: Technology Characteristics (Karakteristik

Teknologi) berpengaruh pada Use Process

(Proses Penggunaan)

H5: Context (Hubungan dengan lingkungan)

berpengaruh pada Use Process (Proses

Penggunaan)

H6: Use Process (Proses Penggunaan)

berpengaruh pada Adoption Outcome (Hasil

Penerimaan)

\section{Landasan Teori}

\subsection{Teknologi Third Generation (3G)}

3G adalah singkatan dari Third Generation Technology, istilah untuk generasi dari perkembangan teknologi dan standar telekomunikasi mobile yang didasarkan pada standar yang dikeluarkan oleh lembaga International Telecommunication Union (ITU). 3G menggunakan teknologi spektrum tersebar yang memungkinkan data yang ditransmisikan tersebar pada semua spektrum frekuensi. Penggunaan teknologi tersebut menimbulkan peningkatan kecepatan data dibandingkan dengan teknologi sebelumnya. Kecepatan transmisi data pada teknologi 2G hanya mencapai 9,6 kbps (kilo bit per detik) hingga 14,4 kbps, sedangkan teknologi 3G memungkinkan kecepatan transmisi data meningkat menjadi 144 kbps jika pengguna bergerak dengan kecepatan sangat tinggi. Jika pengguna $3 \mathrm{G}$ bergerak dengan kecepatan rendah, kecepatan transmisi datanya mencapai $384 \mathrm{kbps}$. Kecepatan transmisi data tertinggi sebesar 2 mbps (mega bit per detik) dapat dicapai jika pengguna dalam keadaan diam [2].
Peningkatan kecepatan transmisi data tersebut memungkinkan ditawarkannya beberapa aplikasi baru oleh para operator seluler, diantaranya adalah video call dan mobile TV.

Layanan $3 \mathrm{G}$ di Indonesia dimulai oleh operator seluler Telkomsel yang pada Agustus 2006 meluncurkan layanan 3G komersial pertamanya [3]. Peluncuran layanan $3 \mathrm{G}$ oleh Telkomsel disusul oleh keempat operator seluler lain yaitu PT. Indosat, PT. Excelcomindo Pratama, PT. Hutchison CP Telecommunications, dan PT. Natrindo Telepon Seluler. Terhitung Maret 2008, seluruh operator seluler tersebut telah menawarkan layanan 3G dengan jenis layanan yang bervariasi. Jenis layanan dasar $3 \mathrm{G}$ dari para operator seluler di Indonesia adalah video call, mobile TV, video streaming, akses internet, serta beragam konten yang dapat di-download.

Sejak teknologi 3G dikenal di Indonesia, banyak tanggapan yang muncul dan diantaranya bernada negatif. Salah satu tanggapan negatif yang cukup populer terhadap teknologi $3 \mathrm{G}$ di Indonesia adalah tarifnya yang dinilai masih terlalu mahal [4]. Beberapa kalangan juga menilai bahwa teknologi sebelumnya sudah memenuhi kebutuhan masyarakat Indonesia sehingga peluncuran teknologi $3 \mathrm{G}$ di Indonesia belum terlalu diperlukan [5].

Selain tanggapan negatif, muncul pula tanggapan positif bagi penerapan $3 \mathrm{G}$ di Indonesia. Berbagai kepentingan dimudahkan dari sisi waktu, tempat dan biaya. Rapat jarak jauh dimungkinkan tanpa keharusan salah satu pihak untuk mendatangi pihak yang lain. Akses informasi yang lebih cepat, kapan saja, dan dimana saja ketika diperlukan. Bahkan pelanggan dapat tetap mengakses hiburan dan mengisi waktu dalam kemacetan [6].

Apapun tanggapan masyarakat, 3G telah diimplementasikan di Indonesia. Jumlah penggunanya telah mencapai peringkat sepuluh dari negara-negara pengguna $3 G$ di dunia [1]. Hal ini menunjukkan bahwa adopsi $3 \mathrm{G}$ di Indonesia tidak seburuk yang pernah diperkirakan, bahkan antusiasme masyarakat dalam menyambut 3G cukup tinggi untuk sebuah teknologi yang masih terbilang mahal ini [6]. Kenyataan ini dapat memberikan dampak positif terhadap perkembangan $3 \mathrm{G}$ selanjutnya.

\subsection{Structural Equation Modeling (SEM)}

Structural Equation Modeling (SEM) adalah suatu teknik statistik yang digunakan untuk melakukan pengujian terhadap suatu model sebab-akibat dengan menggunakan kombinasi dari teori yang ada dan data kuantitatif telah dikumpulkan. SEM mengakomodasi kemampuan dari berbagai teknik statistik yang telah dikenal sebelumnya yaitu menggabungkan antara 
kemampuan teknik path analysis dengan factor analysis. Secara umum, jika pada suatu model SEM terdapat beberapa variabel laten yang saling berpengaruh dan variabel-variabel laten tersebut hanya diukur dengan satu indikator, maka model tersebut termasuk ke dalam kasus path analysis. Di lain pihak, suatu model SEM dengan variabel laten yang diukur dengan beberapa indikator tetapi tidak memiliki hubungan sebab-akibat dengan variabel laten lain merupakan kasus confirmatory factor analysis.

Penggabungan dari beberapa teknik tersebut menghasilkan teknik yang serupa dengan teknik multiple regression, tetapi SEM memiliki beberapa keunggulan jika dibandingkan dengan teknik multiple regression. Kesamaan antara beberapa teknik statistik yang disebutkan di atas beserta keunggulan SEM dibandingkan dengan masing-masing teknik tersebut dirangkum pada Tabel 1 .

Terdapat dua bagian dalam setiap model SEM. Bagian pertama adalah measurement model, yaitu bagian dari model SEM yang mewakili hubungan antara setiap variabel laten dengan indikatornya, seperti pada teknik factor analysis. Bagian kedua adalah structural model, yaitu bagian dari model SEM yang mewakili hubungan antara tiap variabel laten seperti pada teknik path analysis. Variabelvariabel yang terdapat dalam model SEM juga dapat dibagi menjadi dua macam, yaitu variabel eksogen dan variabel endogen. Variabel eksogen adalah variabel yang bersifat independen, sedangkan variabel endogen adalah variabel yang bersifat dependen ataupun variabel yang berperan sebagai mediator.

Langkah pertama dalam teknik SEM adalah menentukan variabel independen yang akan mempengaruhi variabel dependen dengan menggunakan tujuan penelitian dan teori-teori pendukungnya. Beberapa hubungan sebab-akibat dari beberapa variabel akan menghasilkan structural model, dengan sifat alaminya yang memungkinkan variabel dependen pada suatu hubungan dapat menjadi variabel independen pada hubungan yang lain. Selanjutnya, hubungan-hubungan tersebut akan diterjemahkan menjadi rangkaian persamaan. Kemudian peneliti melakukan pemilihan jenis input matrix dan estimasi model yang akan digunakan dalam penelitian. Selanjutnya seluruh perhitungan dilakukan dan siap untuk dievaluasi kelayakannya dan diinterpretasi hasilnya [7].

Jika Structural Equation Modeling diterapkan secara benar akan menghasilkan pembuktian yang kuat atas berbagai hubungan sebab-akibat antar variabel.
Tabel 1. Keunggulan SEM

\begin{tabular}{|c|c|c|}
\hline $\begin{array}{r}\text { Teknik } \\
\text { Statistik }\end{array}$ & $\begin{array}{c}\text { Kesamaan } \\
\text { dengan SEM }\end{array}$ & Keunggulan SEM \\
\hline $\begin{array}{c}\text { Multiple } \\
\text { regression }\end{array}$ & $\begin{array}{l}\text { Variabel dependen } \\
\text { di dalam suatu } \\
\text { model SEM } \\
\text { merupakan hasil } \\
\text { penjumlahan dari } \\
\text { setiap variabel } \\
\text { independen yang } \\
\text { dikalikan dengan } \\
\text { koefisien masing- } \\
\text { masing ditambah } \\
\text { nilai error. }\end{array}$ & $\begin{array}{l}\text { - Menggabungkan } \\
\text { beberapa kasus } \\
\text { multiple regression } \\
\text { secara bersamaan } \\
\text { dalam satu model. } \\
\text { - Setiap variabel } \\
\text { dapat diukur dari } \\
\text { beberapa indikator. } \\
\text { - Analisa untuk } \\
\text { kelompok responden } \\
\text { yang berbeda. } \\
\text { - Tampilan lebih } \\
\text { representatif. }\end{array}$ \\
\hline Path Analysis & $\begin{array}{l}\text { Memperhatikan } \\
\text { pengaruh langsung } \\
\text { dan tidak langsung } \\
\text { dari variabel- } \\
\text { variabel } \\
\text { independen } \\
\text { terhadap variabel- } \\
\text { variabel dependen. }\end{array}$ & $\begin{array}{l}\text { Setiap variabel dapat } \\
\text { dijadikan variabel } \\
\text { laten yang diukur dari } \\
\text { beberapa variabel } \\
\text { manifest sebagai } \\
\text { indikatornya. }\end{array}$ \\
\hline $\begin{array}{c}\text { Confirmatory } \\
\text { Factor } \\
\text { Analysis }\end{array}$ & $\begin{array}{l}\text { Terdapat variabel } \\
\text { laten yang diukur } \\
\text { dari beberapa } \\
\text { indikator. }\end{array}$ & $\begin{array}{l}\text { Dapat } \\
\text { menggambarkan } \\
\text { hubungan antara } \\
\text { variabel laten. }\end{array}$ \\
\hline
\end{tabular}

\subsection{Sarker's and Wells' Framework}

Sarker dan Wells, beranggapan bahwa perkembangan mobile commerce sangat tergantung pada tingkat adopsi masyarakat terhadap perangkat mobile. Mereka menyadari bahwa sudah terdapat model-model yang telah umum digunakan untuk mengukur tingkat adopsi teknologi, tetapi mereka memiliki alasan tersendiri untuk tidak menggunakan model-model yang telah ada sebelumnya. Menurut Sarker dan Wells, jika mereka menggunakan modelmodel tersebut, akan terdapat kemungkinan terabaikannya faktor-faktor khusus sehubungan dengan penggunaan perangkat mobile. Oleh karena itu, maka Sarker dan Wells mengembangkan model untuk mengukur tingkat adopsi perangkat mobile dengan faktor-faktor yang berasal dari sudut pandang para pengguna. Model tersebut digambarkan pada Gambar 1.

Model yang ditawarkan, selanjutnya akan disebut Sarker's and Wells' Framework, terdiri dari 3 proses. Proses pertama adalah masukan (input) kemudian penggunaan (use) yang terdiri dari 2 tahap dan berakhir pada keluaran (output) yang berarti hasil dari proses penggunaan yaitu keputusan dan perilaku pengguna dalam adopsi perangkat mobile.

Proses masukan (input) terdiri dari 5 elemen yaitu:

1. Individual Characteristics atau karakteristik individu adalah faktor-faktor yang berhubungan dengan sifat dasar manusia pada umumnya, termasuk didalamnya yaitu usia, 


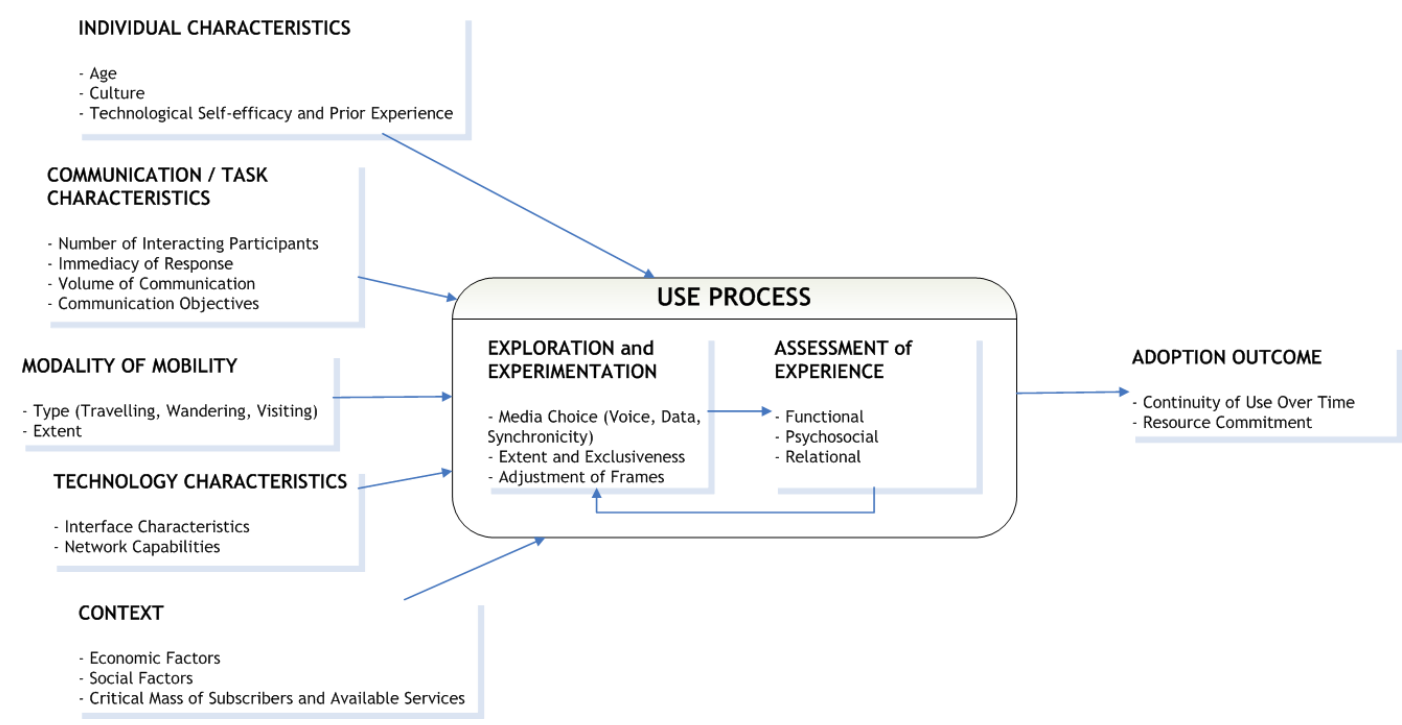

Gambar 1. Framework Sarker dan Wells

budaya, dan kepercayaan diri dalam menggunakan teknologi serta pengalaman yang didapat dari penggunaan teknologi yang sebelumnya.

2. Communication Characteristics atau karakteristik komunikasi adalah faktor-faktor yang berhubungan dengan pola-pola dan jenis komunikasi yang biasanya dilakukan oleh seseorang apakah komunikasi yang dilakukan tersebut adalah komunikasi satu arah, dua arah, atau lebih. Selanjutnya apakah komunikasi yang dilakukan bergantung pada waktu (time-sensitive) dan harus dilakukan saat itu juga. Kemudian apakah komunikasi tersebut singkat atau panjang. Terakhir adalah tujuan dari komunikasi itu sendiri, apakah komunikasi yang dilakukan bertujuan untuk menyampaikan informasi, menerima informasi, atau untuk melakukan komunikasi dua arah yang selaras.

3. Modality of Mobility adalah faktor-faktor yang berhubungan dengan sifat mobilitas dari perangkat mobile. Jenis mobilitas apakah yang sering dilakukan oleh para pengguna perangkat mobile, dan apakah dengan penggunaan perangkat mobile mereka merasakan manfaat ketika melakukan perjalanan tersebut.

4. Technology Characteristics atau karakteristik teknologi adalah faktor-faktor yang berhubungan dengan sisi kemudahan penggunaan perangkat mobile dan sisi jaringan yang mendukung penggunaannya.

5. Context adalah faktor-faktor yang berhubungan dengan keadaan sekitar seperti faktor ekonomi, faktor sosial dan pengguna perangkat sejenis lainnya.

Selanjutnya adalah proses penggunaan yang terdiri dari dua tahap yang saling mempengaruhi, yaitu:

1. Exploration and Experimentation yang dimaksud disini adalah proses eksplorasi dan percobaan yang dilakukan dengan perangkat mobile, termasuk di dalamnya media yang dipilih ketika menggunakan perangkat mobile, frekuensi penggunaan perangkat mobile dibandingkan dengan perangkat lain, dan proses penyesuaian perilaku untuk mengatasi kekurangan dari perangkat mobile itu sendiri.

2. Assessment of Experience adalah proses penilaian atas pengalaman yang dialami berkaitan dengan eksplorasi dan percobaan terhadap perangkat mobile yang telah dilakukan sebelumnya. Penilaian dilakukan dari sisi fungsionalitas perangkat, keadaan sosial pengguna, dan dari sisi hubungan pengguna dengan lingkungan di sekitarnya.

Terakhir adalah hasil penerimaan perangkat mobile yang disebut dengan Adoption Outcome. Pengalaman yang baik ketika eksplorasi dilakukan akan tercermin dalam penilaian yang baik sehingga berpengaruh terhadap perilaku dan keputusan penerimaan perangkat mobile. Tingkat penerimaan oleh pengguna dibedakan berdasarkan tingkat komitmen dalam menyediakan waktu, usaha, dan uang untuk dapat terus menggunakan perangkat mobile.

Dalam Sarker's And Wells' Framework terdapat beberapa hubungan antara faktor-faktor masukan, proses penggunaan, dan hasil penerimaan. Faktor- 


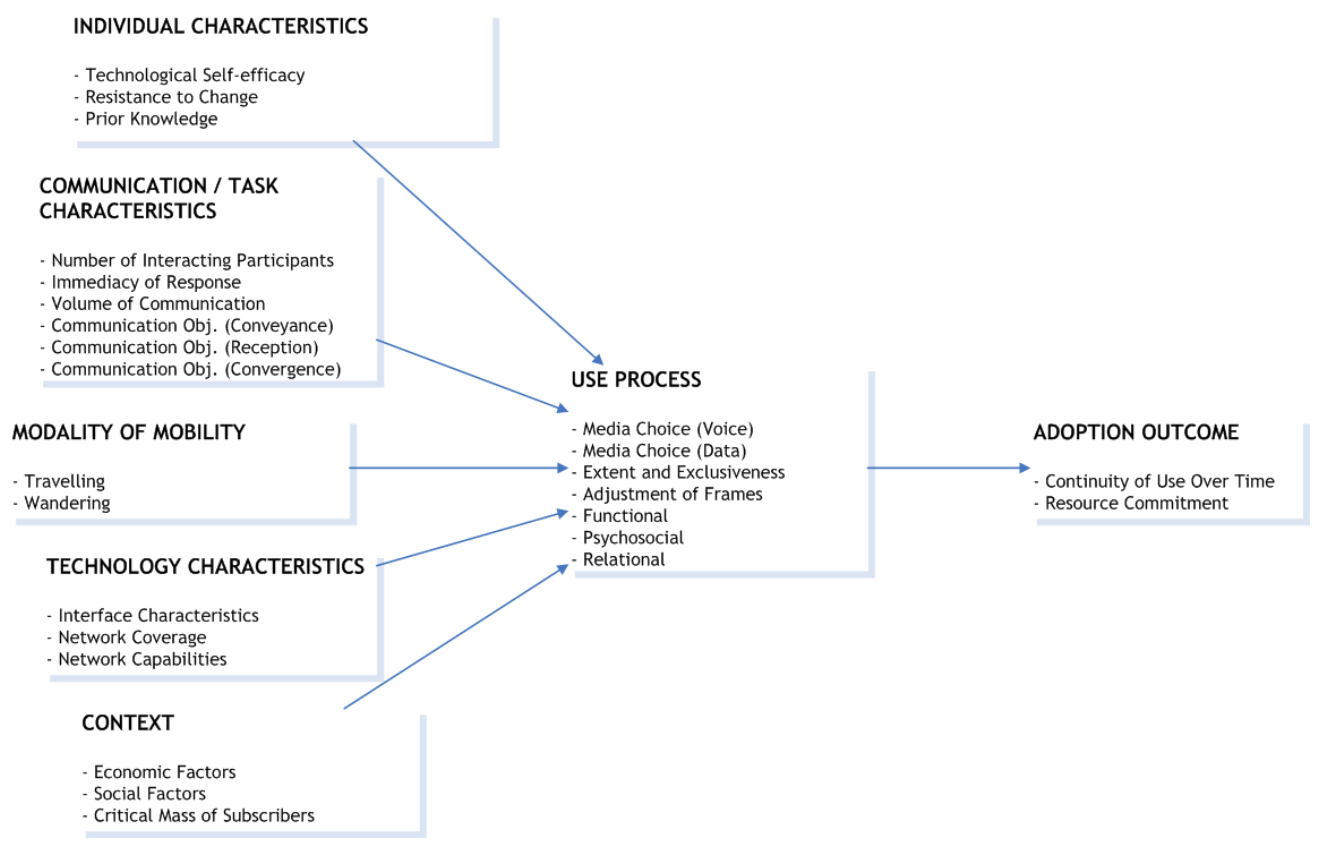

Gambar 2. Framework Sarker dan Wells yang Dimodifikasi

faktor masukan mempengaruhi proses penggunaan perangkat mobile secara keseluruhan. Tahapantahapan dalam proses penggunaan juga saling berpengaruh seperti yang telah dijelaskan sebelumnya. Hubungan terakhir adalah proses penggunaan secara keseluruhan berpengaruh pada hasil penerimaan pengguna terhadap perangkat mobile.

\subsection{Sarker's and Wells' Framework dalam Penelitian Ini}

Dalam penelitian ini, Sarker's and Wells' Framework akan diadaptasi dengan berbagai penyesuaian. Alasan peneliti memilih untuk menggunakan Sarker's and Wells' Framework sebagai dasar hipotesis penelitian adalah karena model-model adaptasi teknologi yang lain seperti TAM dan UTAUT dinilai hanya menggambarkan teknologi secara umum sehingga kurang mempertimbangkan faktor-faktor khusus sehubungan dengan sifat dari $3 \mathrm{G}$. 3G sebagai teknologi yang ditujukan untuk digunakan dengan perangkat mobile, mengadaptasi sifat-sifat khusus dari perangkat mobile, dan sifat-sifat khusus tersebut menjadi faktor yang dipertimbangkan dalam Sarker's and Wells' Framework.

Seperti yang telah dijelaskan sebelumnya, terdapat beberapa penyesuaian terhadap Sarker's and Wells' Framework yang dilakukan dalam penelitian ini. Penyesuaian-penyesuaian tersebut antara lain:

1. Menggabungkan indikator dalam variabel Use Process

Pada penelitian ini, proses pengumpulan data hanya dilakukan satu kali sehingga tidak memerlukan pembagian variabel Use Process menjadi dua tahap. Oleh karena itu, peneliti memutuskan untuk menggabungkan seluruh indikator dari kedua tahap tersebut menjadi indikator dari variabel Use Process.

2. Menyesuaikan indikator yang digunakan dalam variabel Individual Characteristics Pada Sarker's and Wells' Framework, variabel Individual Characteristics melibatkan tiga indikator yaitu indikator umur (Age), budaya (Culture), dan kepercayaan diri untuk menggunakan teknologi (Technological SelfEfficacy). Populasi dari penelitian ini adalah mahasiswa Universitas Indonesia yang menggunakan 3G. Berdasarkan populasi tersebut, maka penelitian ini tidak mengikutsertakan indikator umur, karena populasi berada pada kisaran umur yang kurang lebih setara. Sedangkan indikator budaya tidak diikutsertakan dalam penelitian ini karena keragaman budaya di Indonesia dianggap tidak menentukan perilaku konsumsi perangkat seluler [8].

Selain terdapat indikator yang tidak diikutsertakan, terdapat pula indikator baru yang ditambah karena dianggap diperlukan untuk menjelaskan variabel Individual Characteristics. Indikator-indikator tersebut adalah Resistance to Change dan Prior Knowledge untuk konstruk Individual Characteristics. 
3. Menyesuaikan indikator yang digunakan dalam variabel Communication Characteristics Pada Sarker's and Wells' Framework, variabel Communication Characteristics melibatkan indikator Communication Objectives yang bermaksud menggambarkan tujuan komunikasi yang dilakukan. Dalam penelitian ini indikator tersebut disesuaikan dengan skala Likert yang digunakan, sehingga dibagi menjadi tiga indikator baru yang masing-masing menyatakan tujuan komunikasi yang cocok dilakukan dengan bantuan teknologi 3G.

4. Menyesuaikan indikator yang digunakan dalam variabel Technology Characteristics

Pada Sarker's and Wells' Framework, variabel Technology Characteristics melibatkan indikator Network Capabilities yang menggambarkan dua hal yang berbeda yaitu kestabilan jaringan dan luasnya jaringan. Kedua hal tersebut masing-masing menjadi indikator baru dalam variabel Technology Characteristics karena satu indikator tidak dapat mengukur dua hal yang berbeda.

5. Menyesuaikan indikator yang digunakan dalam variabel Use Process

Pada Sarker's and Wells' Framework, variabel Use Process melibatkan indikator Media Choice yang bermaksud menggambarkan media yang digunakan. Dalam penelitian ini indikator tersebut disesuaikan dengan skala Likert yang digunakan, sehingga dibagi menjadi dua indikator baru yang masingmasing menyatakan layanan 3G yang paling banyak digunakan.

Dari berbagai penyesuaian tersebut, dihasilkanlah sebuah framework baru yang merupakan hasil modifikasi dari Sarker's and Wells' Framework seperti yang ditampilkan pada Gambar 2.

\section{Metode Penelitian}

Peneliti menyusun kuesioner dari model SEM yang dibangun, kemudian menyebarkannya pada sampel. Hasil yang diperoleh dari penyebaran kuesioner tersebut selanjutnya akan dianalisis untuk mencapai tujuan penelitian. Proses penyusunan model sampai interpretasi hasil perhitungan akan dilakukan sesuai dengan teknik statistik yang digunakan, yaitu dengan mengacu pada tahapan SEM.

\subsection{Populasi dan Sampel}

Populasi dari penelitian ini adalah seluruh mahasiswa Universitas Indonesia yang menggunakan 3G. Menurut Hair et. al. [7], ukuran sampel yang dianjurkan untuk penggunaan metode SEM adalah

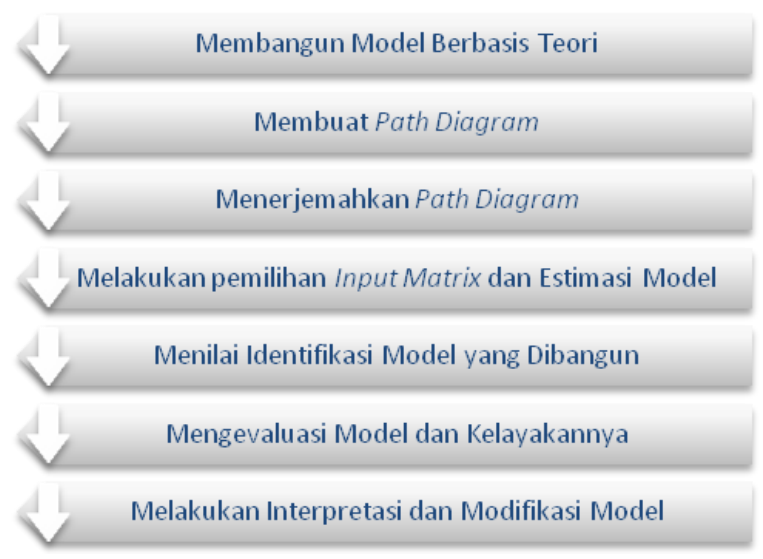

Gambar 3. Tahapan SEM

100-200 sampel, sehingga penulis memutuskan untuk mengambil 110 sampel. Metode yang digunakan untuk pengambilan sampel adalah accidental sampling. Teknik sampling tersebut dipilih karena ketiadaan data yang pasti tentang jumlah pengguna 3G di Universitas Indonesia. Accidental sampling dapat memudahkan peneliti untuk pengambilan data dari para pengguna $3 \mathrm{G}$ di Universitas Indonesia yang dapat ditemui.

\subsection{Teknik Pengolahan dan Analisis Data}

Setelah data primer berhasil dikumpulkan dari para responden, maka data tersebut perlu diolah agar sesuai dengan kebutuhan penelitian. Pengolahan dan analisis data akan dilakukan dengan menggunakan metode Structural Equation Modeling (SEM).

SEM bertujuan untuk menguji hubungan yang terjadi antara variabel-variabel yang terdapat pada sebuah model. Gambar 3 menampilkan tahapan yang harus dilakukan dalam pengolahan data dengan menggunakan SEM.

Selanjutnya akan dijelaskan secara lebih detil mengenai tahapan-tahapan SEM yang dilakukan dalam penelitian ini.

\subsubsection{Membangun Model Berbasis Teori}

Setelah tujuan penelitian ditentukan, saatnya untuk membangun model berbasis teori. Teori-teori tersebut akan menjadi justifikasi untuk tiap aspek dalam SEM. Model berbasis teori ini terdiri dari variabel-variabel yang dibutuhkan, dan hubungan antar tiap variabel-variabel tersebut.

\subsubsection{Membuat Path Diagram}

Path diagram adalah visualisasi hubungan antar variabel yang tidak hanya dapat menggambarkan perkiraan hubungan sebab-akibat antar variabel tetapi juga menggambarkan hubungan antar konstruk 
dengan indikator-indikatornya.

Path diagram biasanya terdiri dari dua elemen penting yaitu konstruk dan hubungan diantaranya. Setiap konstruk mewakili suatu variabel dan biasanya digambarkan dengan bentuk oval, sedangkan hubungan antar konstruk biasanya digambarkan dengan tanda panah.

\subsubsection{Menerjemahkan Path Diagram}

Path diagram yang telah dibuat selanjutnya akan diterjemahkan menjadi persamaan untuk structural model dan measurement model. Penerjemahan structural model dapat dilakukan secara langsung oleh tools yang digunakan sehingga tidak memerlukan penerjemahan secara manual.

\subsubsection{Melakukan pemilihan Input Matrix dan Estimasi Model}

SEM hanya menggunakan matriks korelasi atau matriks varians-kovarians sebagai masukan dalam perhitungannya, sehingga diperlukan diagnosa pada data yang tersedia terlebih dahulu, agar data memenuhi asumsi dasar pada SEM. Asumsi-asumsi tersebut adalah data harus bersih dari data ekstrim (outlier), memiliki distribusi normal, dan tidak terdapat multikolinearitas antar indikator yang ada. Berikut akan dijelaskan cara pemeriksaan asumsiasumsi tersebut.

1. Pemeriksaan Outlier

Untuk memeriksa keberadaan outlier, peneliti menggunakan metode Mahalanobis distance. Dalam perhitungan Mahalanobis distance, terdapat angka p1 dan p2. Suatu data merupakan outlier jika nilai p1 dan p2 dari data tersebut kurang dari 0.05. Untuk membersihkan data, maka peneliti harus menghapus data-data yang memiliki nilai $\mathrm{p} 1$ dan p2 kurang dari 0.05.

2. Pemeriksaan Normalitas Data

Untuk melakukan pemeriksaan distribusi data, peneliti menggunakan nilai kritis (c.r.) dari kemiringan data secara keseluruhan dan membandingkannya dengan nilai Z. Suatu data dikatakan memiliki distribusi normal jika nilai c.r. berada pada kisaran - 2.58 sampai + 2.58.

3. Pemeriksaan Multikolinearitas

Keberadaan multikolinearitas dapat dilihat dari korelasi antar indikator. Jika nilai korelasi antar indikator mendekati 1, maka kedua indikator tersebut mengukur hal yang sama dan salah satu indikator tersebut harus dihapus dari perhitungan.

Setelah data yang diinginkan telah didapat, maka input matriks dapat dipilih sesuai kebutuhan. Matriks varians-kovarians memiliki kemampuan untuk membandingkan kelompok sampel yang berbeda. Di lain pihak, matriks korelasi lebih luas aplikasinya dan cocok jika tujuan penelitian yang dilakukan hanya untuk memahami pola hubungan antar konstruk tanpa menjelaskan varians dari konstruk tertentu.

Perhitungan koefisien structural dari suatu model SEM dapat dilakukan dengan berbagai cara, seperti MLE (Maximum Likelihood Estimation), WLS (Weighted Least Squares), GLS (Generalized Least Squares), OLS (Ordinary Least Squares), dan ULS (Unweighted Least Squares). Cara yang paling umum digunakan adalah MLE, kecuali dalam kasus-kasus khusus. MLE melakukan estimasi berdasarkan atas kemungkinan bahwa kovarians dari populasi sama dengan nilai koefisien yang diperkirakan.

\subsubsection{Menilai Identifikasi Model yang Dibangun}

Penilaian identifikasi model dilakukan dengan menghitung nilai degrees of freedom dari model tersebut. Terdapat tiga jenis model berdasarkan nilai degrees of freedom-nya. Pertama, just-identified model, yaitu model dengan nilai degrees of freedom tepat 0 . Kedua, over-identified model, yaitu model dengan nilai degrees of freedom positif. Model ini adalah tujuan untuk seluruh model struktural. Terakhir, under-identified model, yaitu model dengan nilai degrees of freedom negatif. Model seperti ini menunjukkan bahwa informasi yang tersedia tidak memenuhi kebutuhan sehingga tidak dapat diestimasi hasilnya.

\subsubsection{Mengevaluasi Kelayakan Model}

Langkah pertama yang harus dilakukan pada hasil penelitian dengan SEM adalah memeriksa keberadaan offending estimates pada model. Jika tidak terdapat offending estimates pada model, maka evaluasi kelayakan dapat diteruskan. Offending estimates adalah nilai koefisien estimasi dari model yang melampaui batas yang dapat diterima. Contoh kasus yang umum terjadi adalah nilai variances dari suatu variabel negatif, standardized coefficients yang mendekati 1, dan standard error yang tinggi. Setelah memastikan bahwa tidak terdapat offending estimates dalam model, uji kelayakan dapat dilanjutkan dengan uji kelayakan terhadap model secara keseluruhan. Terdapat berbagai macam uji kelayakan model secara keseluruhan yang dapat dipilih, diantaranya adalah chi-square $\left(x^{2}\right)$, GFI, AGFI, SRMR, NFI, CFI, TLI, dan RMSEA. Peneliti akan menggunakan empat dari berbagai macam tes tersebut dan akan dijelaskan berikut ini:

- Chi-square $\left(\mathrm{x}^{2}\right)$

Nilai chi-square dari suatu model harus tidak signifikan (> .05) jika model tersebut fit. 
- $\quad$ GFI (Goodness-of-fit index)

Nilai GFI untuk model yang fit seharusnya mendekati 1.

- TLI (Tucker-Lewis index)

Nilai TLI untuk suatu model yang fit seharusnya mendekati 1 .

- RMSEA (Root Mean Square Error of Approximation).

Menurut konvensi, nilai yang direkomendasikan untuk model yang fit adalah $<=.06$.

Jika tes-tes tersebut menghasilkan nilai yang berada pada kisaran yang direkomendasi, maka pengujian kelayakan model dapat dilanjutkan. Kelayakan model ditinjau dari dua sisi, yaitu uji kelayakan measurement model, dan uji kelayakan structural model.

Uji kelayakan terhadap measurement model berfungsi untuk melihat apakah suatu variabel telah diukur dengan benar oleh masing-masing indikatornya. Suatu variabel dapat dikatakan benar terukur oleh masing-masing indikatornya jika memiliki nilai variance extracted lebih dari 0.5 .

Uji kelayakan structural model berfungsi untuk melihat hubungan antar variabel yang telah didefinisikan pada pembangunan model, apakah hubungan antar variabel tersebut signifikan, dan seberapa besar hubungannya. Uji structural model juga sering disebut sebagai uji hipotesis. Untuk menilai signifikansi dari suatu hubungan antar variabel, peneliti dapat melihat nilai $\mathrm{p}$ dari hasil perhitungan nilai regresi hubungan tersebut. Pada hasil perhitungan dengan menggunakan AMOS, hubungan yang signifikan akan ditandai dengan $\mathrm{p}$ yang bernilai $* * *$.

\subsubsection{Melakukan Interpretasi dan Modifikasi Model}

Setelah melakukan seluruh tahapan SEM, peneliti biasanya akan mencari cara untuk meningkatkan kecocokan model dengan data yang ada. Hal tersebut mengakibatkan kebutuhan untuk melakukan spesifikasi ulang terhadap suatu model. Setiap spesifikasi ulang dilakukan terhadap suatu model, maka peneliti harus mengulang tahapan SEM dari tahap empat, yaitu melakukan uji asumsi data terhadap model yang telah diubah, baru kemudian melanjutkannya dengan tahap selanjutnya.

\section{Analisis Dada dan Pembahasan}

Responden penelitian terdiri dari 110 mahasiswa UI yang mayoritas adalah berjenis kelamin perempuan, berumur 21 tahun, dan berasal dari Fakultas Ilmu Sosial dan Ilmu Politik. Dari para responden tersebut, mayoritas pengguna adalah pengguna yang baru mengenal $3 \mathrm{G}$ kurang dari 6 bulan yang lalu. Mereka mengenal 3G paling banyak dari iklan (75\%) dan hampir seluruh responden mengakses 3G langsung dari telepon genggam (96\%).

Operator yang paling digunakan oleh para responden adalah Telkomsel (35\%) dan dari fasilitasfasilitas $3 \mathrm{G}$ yang ditawarkan oleh para operator tersebut, yang paling banyak disukai adalah video call yang dipilih oleh $66 \%$ responden. Mayoritas responden merasa telah puas dengan layanan yang diberikan (73\%), hanya saja mereka tetap menginginkan tarif yang lebih murah $(77 \%)$ dan peningkatan kecepatan layanan $(65 \%)$.

Tabel 2. Variabel Beserta Teori Pendukung

\begin{tabular}{|c|c|c|}
\hline Variabel & Indikator & $\begin{array}{c}\text { Teori } \\
\text { Pendukung }\end{array}$ \\
\hline \multirow{3}{*}{$\begin{array}{l}\text { Individual } \\
\text { Characteristics } \\
\text { (Karakteristik } \\
\text { Individu) }\end{array}$} & $\begin{array}{l}\text { Technological Self } \\
\text { efficacy }\end{array}$ & {$[9,10]$} \\
\hline & Resistant to change & {$[11]$} \\
\hline & Prior knowledge & {$[12]$} \\
\hline \multirow{4}{*}{$\begin{array}{l}\text { Communication } \\
\text { Characteristics } \\
\text { (Karakteristik } \\
\text { Komunikasi) }\end{array}$} & $\begin{array}{l}\text { Number of interacting } \\
\text { participants }\end{array}$ & \\
\hline & Immediacy of response & \\
\hline & $\begin{array}{l}\text { Volume of } \\
\text { communication }\end{array}$ & {$[13]$} \\
\hline & $\begin{array}{l}\text { Communication } \\
\text { objectives }\end{array}$ & \\
\hline \multirow{2}{*}{$\begin{array}{l}\text { Modality of } \\
\text { Mobility } \\
\text { (Karakteristik } \\
\text { Mobilitas) }\end{array}$} & Travelling & {$[14]$} \\
\hline & Wandering & {$[14]$} \\
\hline \multirow{2}{*}{$\begin{array}{l}\text { Technology } \\
\text { Characteristics } \\
\text { (Karakteristik } \\
\text { Teknologi) }\end{array}$} & $\begin{array}{l}\text { Interface } \\
\text { characteristics }\end{array}$ & {$[10]$} \\
\hline & Network capabilities & \\
\hline \multirow{3}{*}{$\begin{array}{l}\text { Context } \\
\text { (Hubungan } \\
\text { dengan } \\
\text { lingkungan) }\end{array}$} & Economic factors & \\
\hline & Social factors & \\
\hline & $\begin{array}{l}\text { Critical mass of } \\
\text { subscribers and } \\
\text { available services }\end{array}$ & {$[15]$} \\
\hline \multirow{6}{*}{$\begin{array}{l}\text { Use Process } \\
\text { (Proses } \\
\text { Penggunaan) }\end{array}$} & Media choice & \\
\hline & $\begin{array}{l}\text { Extent and } \\
\text { exclusiveness }\end{array}$ & \\
\hline & Adjustment of frames & \\
\hline & Functional & {$[10]$} \\
\hline & Psychosocial & {$[15]$} \\
\hline & Relational & \\
\hline \multirow{2}{*}{$\begin{array}{l}\text { Adoption } \\
\text { Outcome (Hasil } \\
\text { Penerimaan) }\end{array}$} & $\begin{array}{l}\text { Continuity of use over } \\
\text { time }\end{array}$ & \\
\hline & Resource commitment & \\
\hline
\end{tabular}

\subsection{Analisis Data Menggunakan SEM}

Data yang didapatkan dari para responden kemudian diolah untuk mencapai tujuan penelitian. Pengolahan data menggunakan teknik SEM yang 
telah dibahas pada Bab 3. Metode Penelitian.

\subsubsection{Membangun Model Berbasis Teori}

Model yang digunakan dalam penelitian ini berasal dari Framework milik Sarker dan Wells yang dimodifikasi sesuai dengan keadaan di lapangan saat penelitian ini dilakukan. Tabel 2 berisi tentang rangkuman variabel-variabel yang akan dibahas serta teori-teori pendukungnya.

\subsubsection{Membuat Path Diagram}

Model teoritis yang telah dibangun kemudian digambarkan dalam bentuk path diagram. Tujuan dibentuknya path diagram disini adalah untuk memudahkan visualisasi hubungan sebab-akibat yang akan diuji sekaligus sebagai input untuk tools yang digunakan. Path diagram untuk penelitian ini digambarkan dalam Gambar 4.

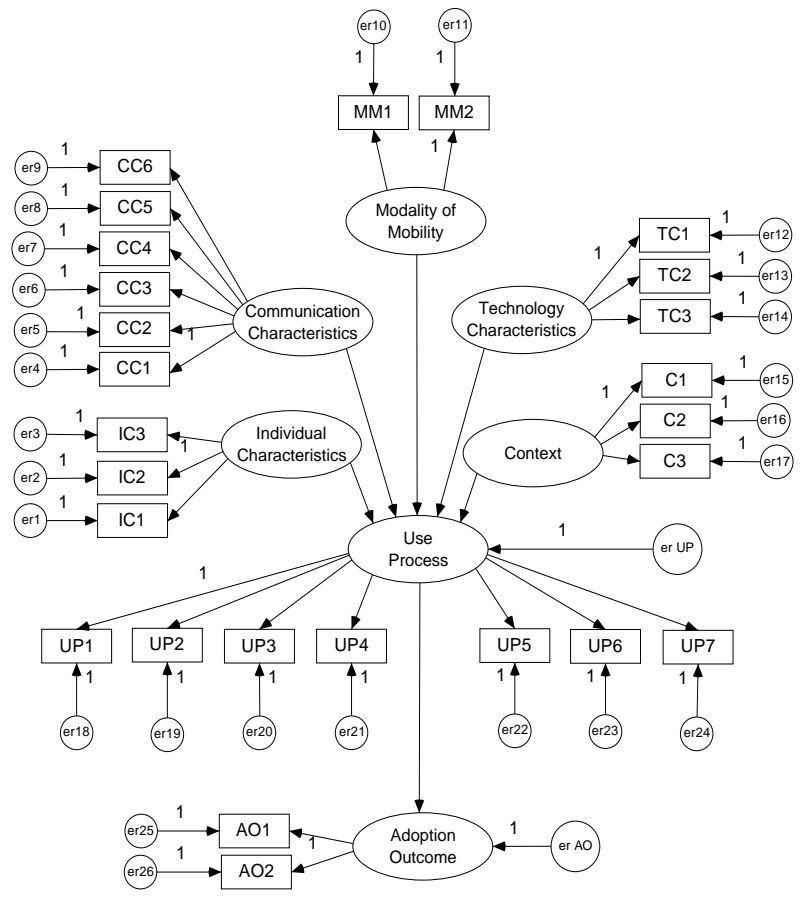

Gambar 4. Tahapan SEM

\subsubsection{Menerjemahkan Path Diagram}

Path diagram yang telah dibangun perlu diterjemahkan ke dalam bentuk persamaan, baik untuk measurement model maupun untuk structural model. Tetapi dalam hal ini, dimana penelitian ini melibatkan AMOS 16 sebagai tools SEM yang digunakan, maka proses penterjemahan tidak perlu dilakukan oleh peneliti secara manual.

\subsubsection{Melakukan Pemilihan Input Matrix dan Estimasi Model}

Sebelum memilih jenis input matrix dan estimasi model, data yang dikumpulkan dari para responden harus diperiksa terlebih dahulu agar memenuhi asumsi yang dibutuhkan oleh teknik SEM. Asumsiasumsi tersebut adalah data harus bersih dari data ekstrim (outlier), memiliki distribusi normal, dan tidak terdapat multikolinearitas antar indikator yang ada. Berikut akan dijelaskan pemeriksaan asumsiasumsi tersebut dalam penelitian ini.

1. Pemeriksaan Outlier

Dari pemeriksaan yang dilakukan dengan menggunakan metode Mahalanobis distance terlihat bahwa terdapat 7 outlier sehingga data tersebut harus dihapus. Setelah ketujuh data tersebut telah dihapus, perhitungan kembali dilakukan dan perhitungan tersebut menunjukkan bahwa data telah bersih dari outlier.

2. Pemeriksaan Normalitas Data

Pemeriksaan terhadap distribusi data dilakukan setelah data bersih dari outlier. Pada hasil perhitungan tersebut, c.r. keseluruhan data bernilai 4.444. Nilai tersebut berada diluar kisaran nilai yang direkomendasikan yaitu -2.58 sampai +2.58 , sehingga data tersebut tidak memiliki distribusi normal.

3. Pemeriksaan Multikolinearitas

Pemeriksaan keberadaan multikoliearitas dilakukan dengan melihat korelasi antar indikator dan terlihat bahwa tidak terdapat nilai korelasi antar indikator yang bernilai mendekato 1, sehingga tidak terdapat multikolinearitas pada data penelitian.

Dari pemeriksaan asumsi-asumsi tersebut, dapat disimpulkan bahwa data sudah bersih dari outlier dan multikolinearitas tetapi distribusinya belum normal. Hal ini dapat diantisipasi dengan menambah jumlah sampel, tetapi sesuai tujuan penelitian yang hanya akan menguji model sesuai dengan data yang diperoleh dari sampel, maka penelitian akan dilanjutkan pada tahap selanjutnya. Fakta distribusi data ini akan diperhitungkan ketika melakukan interpretasi hasil perhitungan pada akhir tahap SEM.

Jenis input matrix yang dipilih adalah matriks kovarians karena matriks kovarians lebih cocok dalam menjelaskan hubungan antar variabel. Estimasi yang dipilih dalam perhitungan penelitian ini adalah Maximum Likelihood. Setelah memilih jenis input matrix dan estimasi model, kalkulasi untuk model penelitian dapat dilakukan. 


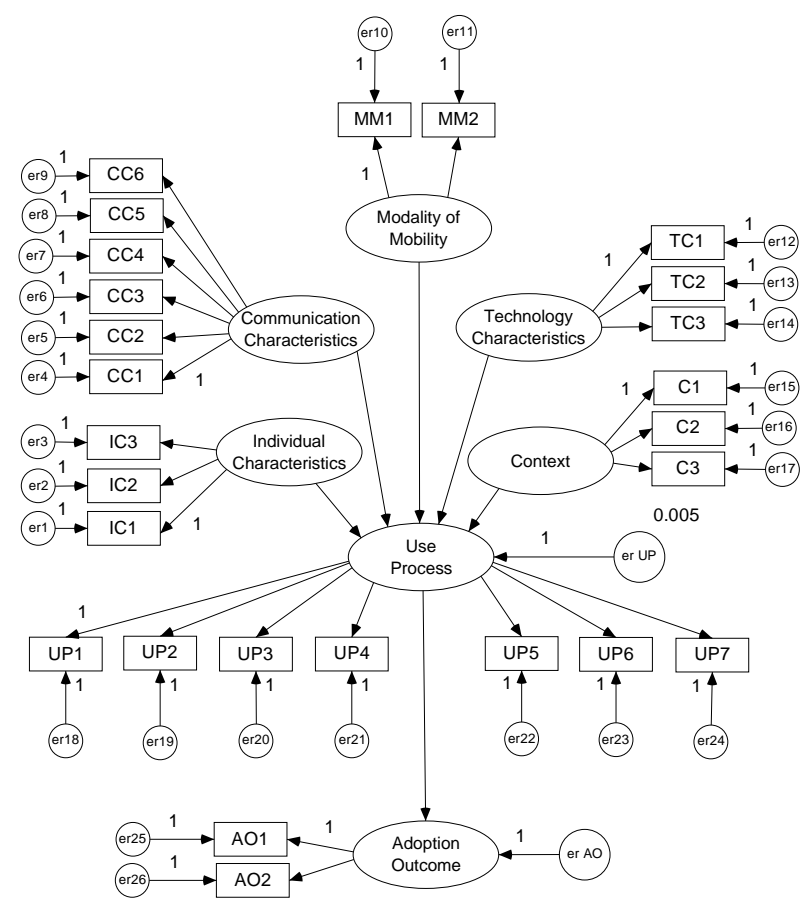

Gambar 1. Model yang Dimodifikasi

\subsubsection{Menilai Identifikasi Model yang Dibangun}

Cara untuk melakukan penilaian identifikasi model adalah dengan menghitung nilai degrees of freedom dari model tersebut. Tabel 4.5 menunjukkan hasil perhitungan AMOS 16 untuk degree of freedom dari model yang dibangun. Hasil perhitungan tersebut menunjukkan nilai degrees of freedom positif (293), sehingga termasuk ke dalam over-identified model. Memperhitungkan hasil identifikasi tersebut, maka proses analisis dapat dilanjutkan.

Tabel 3. Computation of degrees of freedom Number of distinct sample moments: 351

Number of distinct parameters to be estimated: $\quad 58$ Degrees of freedom (351-58): 293

\subsubsection{Mengevaluasi Kelayakan Model}

Setelah menilai identifikasi model, langkah selanjutnya adalah melakukan evaluasi terhadap model penelitian. Tetapi sebelum melakukan evaluasi, harus diperiksa terlebih dahulu kemungkinan keberadaan offending estimate pada model. Pada penelitian ini, AMOS 16 memberikan output berupa keterangan yang menunjukkan bahwa terdapat varians dari suatu variabel yang bernilai negatif (er $\mathrm{UP}=-.007)$.

Jika terdapat nilai varians yang negatif, terdapat kemungkinan hal ini berkaitan dengan keberadaan multikolinearitas pada model. Tetapi pemeriksaan

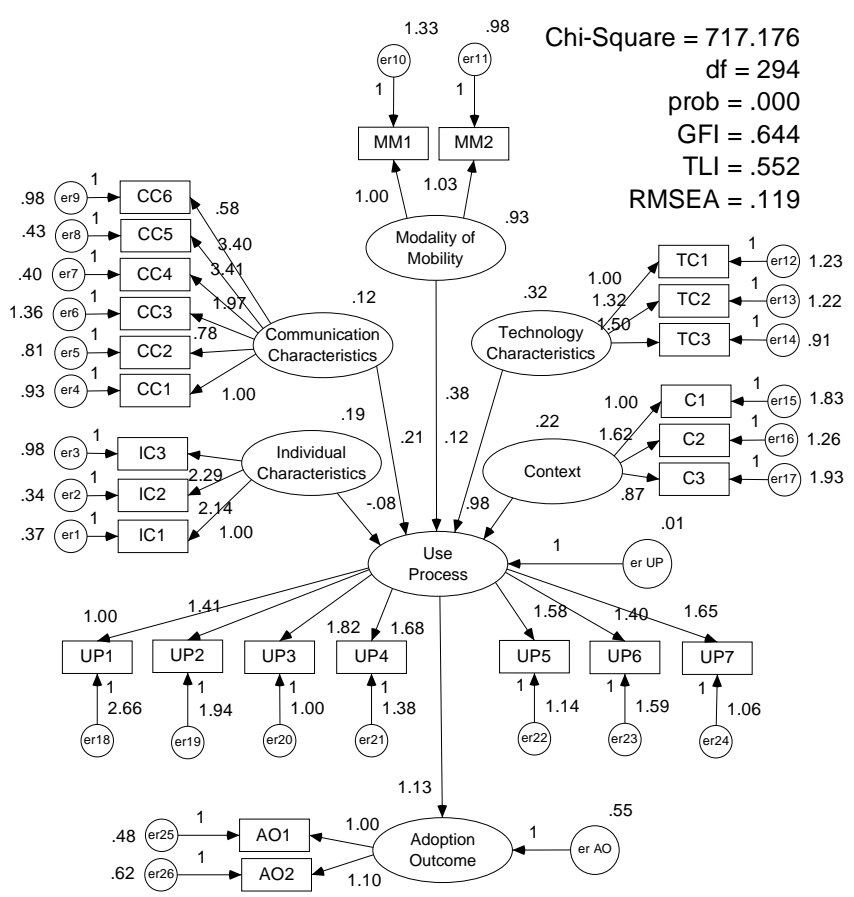

Gambar 6. Output Path Diagram

asumsi pada langkah sebelumnya telah menunjukkan bahwa tidak terdapat multikolinearitas pada model, sehingga hal ini tidak berhubungan dengan multikolinearitas.

Menurut Hair et al., kasus offending estimate dimana terdapat varians dari suatu variabel yang bernilai negatif dapat diatasi dengan pendefinisian nilai varians pada variabel tersebut dengan nilai positif yang sangat kecil (.005). Mengikuti saran tersebut, peneliti melakukan modifikasi model dengan melakukan definisi nilai varians untuk variabel error er UP sebesar .005, sehingga path diagram dari model berubah menjadi seperti digambarkan pada Gambar 5.

Setelah melakukan modifikasi terhadap model, pemeriksaan terhadap kemungkinan terdapatnya kasus offending estimate kembali dilakukan. Kali ini, AMOS menghasilkan output yang menunjukkan bahwa tidak terdapat kasus offending estimate dan proses analisis dapat dilanjutkan pada tahap uji kelayakan model secara keseluruhan.

Proses analisis dilanjutkan pada uji kelayakan model secara keseluruhan. Gambar 6 menunjukkan output AMOS 16 untuk path diagram, beserta nilainilai uji kelayakan untuk model tersebut.

Pada output tersebut, terlihat nilai-nilai dari hasil uji kelayakan model secara keseluruhan. Tabel 4.6 merangkum nilai-nilai tersebut dan nilai yang diharapkan dari masing-masing tes. Dari keempat tes yang dilakukan, ternyata nilai chi-square $\left(x^{2}\right)$, GFI, TLI, dan RMSEA berada di luar kisaran nilai yang 
direkomendasikan $(p=0.000,<0.05$; GFI $=0.644,<$ 0.9 ; TLI $=0.552,<0.9$; RMSEA $=0.119$, > 0.06). Oleh karena hasil tersebut, maka model dinyatakan tidak fit dengan data penelitian sehingga perlu dilakukan spesifikasi ulang terhadap model penelitian.

Hasil uji kelayakan model secara keseluruhan memperlihatan bahwa model tidak cocok dengan data yang ada. Hal ini menyebabkan tidak dapat dilakukan tes lanjutan, karena walaupun hasil uji kelayakan selanjutnya menunjukkan bahwa measurement model dan structural model cocok dengan data yang ada, hasil itu tidak akan berarti apa-apa. Uji kelayakan model berhenti pada tahap ini.

Uji kelayakan structural model yang berfungsi untuk melihat hubungan antar variabel tidak dapat dilakukan, sehingga hipotesis tidak dapat diuji. Melihat keadaan tersebut maka seluruh hipotesis dinyatakan ditolak.

\subsubsection{Melakukan Interpretasi dan Modifikasi Model}

Tahapan-tahapan SEM yang telah dilakukan menunjukkan bahwa model penelitian ini tidak memenuhi standar kelayakan. Hal ini bisa terjadi karena beberapa alasan, seperti distribusi data yang tidak normal, atau variabel-variabel yang tidak terukur dengan baik. Pada tahap terakhir dari teknik SEM ini, biasanya peneliti akan melakukan modifikasi model demi mencapai model yang lebih baik. Tetapi penelitian ini dibatasi pada pengujian model milik Sarker dan Wells sehingga peneliti tidak melakukan modifikasi selanjutnya pada model. Proses analisis data dengan teknik SEM selesai pada tahap ini.

\section{Penutup}

\subsection{Kesimpulan}

Berdasarkan data yang didapat dari para responden dan analisis yang telah dilakukan dengan teknik SEM, maka dapat diambil kesimpulan sehubungan dengan tujuan penelitian, yaitu:

1. Model yang dinyatakan tidak fit dengan data menunjukkan bahwa saat ini framework milik Sarker dan Wells yang digunakan untuk menggambarkan adopsi perangkat mobile tidak cocok diterapkan pada adopsi teknologi $3 \mathrm{G}$ di Indonesia dengan populasi mahasiswa Universitas Indonesia. Ketidaklayakan dari model dan data dalam penelitian ini dapat disebabkan oleh beberapa hal, yaitu distribusi data yang tidak normal dan variabel yang tidak terukur dengan baik.
2. Sesuai dengan tahapan pada teknik SEM, jika suatu model dinyatakan tidak layak secara keseluruhan, maka hubungan antar variabel tidak dapat ditentukan. Oleh karena itu, faktor yang paling berpengaruh dalam adopsi $3 \mathrm{G}$ di Indonesia belum dapat diketahui dari penelitian ini.

\subsection{Saran}

Saran-saran yang dapat peneliti ajukan untuk penelitian sejenis selanjutnya adalah sebagai berikut:

1. Pengujian model yang berbeda

2. Pengembangan alat ukur baru

3. Penambahan jumlah sampel

4. Perluasan populasi

5. Penggunaan metode random sampling

6. Penelitian dilakukan kembali ketika teknologi 3G telah mapan

\section{REFERENSI}

[1] ANTARA News. "Jumlah Pelanggan 3G Telkomsel Masuk 10 Besar Dunia". ANTARA News. 2007. Diakses pada 12 Februari 2008, dari ANTARA News: http://www.antara.co.id/print/?i=1190262718.

[2] Kcm. "Perjalanan Teknologi $1 \mathrm{G}$ ke 3G". Sriwijaya Post, 22 Januari 2006. hal 7.

[3] Haswidi, Andi. INDONESIA: Indonesia finally gets 3G; Telkomsel leading the pack. Asia Media. 2006. Diakses pada 14 April 2008, dari Asia Media:

http://www.asiamedia.ucla.edu/ article. asp?parentid $=51060$.

[4] Hapsari, Muslima. "Tarif 3G Masih Dirasakan Mahal". Tempo Interaktif. 2007. Diakses pada 14 April 2008, dari Tempo Interaktif:

http://www.tempointeraktif.com/hg/ekbis/2007/05 /29/brk,20070529-100867, id.html.

[5] eBizzAsia. "Pesimisme Hadirnya Teknologi 3G". eBizzAsia. 2003. Diakses pada 14 April 2008, dari eBizzAsia:

http://www.ebizzasia.com/01102003/itc,0110,1.htm.

[6] ANTARA News. "Layanan Seluler 3G Jangan Sekedar Era". ANTARA News. 2006. Diakses pada 14 Februari 2008, dari ANTARA News: http://www.antara.co.id/print/?id= 1159591758 .

[7] Hair, Joseph F., Anderson, Rolph E., Tatham, Ronald L., dan Black, William C. Multivariate Data Analysis. Prentice-Hall, Inc. New Jersey. 1998. 
Analisis Pola Adopsi Teknologi 3D pada Kalangan Mahasiswa Universitas Indonesia Berdasarkan Model Sarker dan Wells dengan Menggunakan Teknik Structural Equation Modeling

[8] Irawan, D Handi. Konsumen Indonesia : Makin Sama atau Makin Beda?. Wikimu. 2007. Diakses pada 22 Mei 2008, dari Wikimu: http://www.wikimu.com/news/displaynews.aspx?i $\mathrm{d}=1872$. 